\title{
Food availability and food insecurity in households in the state of Tocantins, Northern Brazil
}

\author{
Disponibilidade de alimentos e insegurança \\ alimentar de domicílios do Estado do \\ Tocantins, Região Norte do Brasil
}

\author{
Eloise SCHOTT' 1 (D) 0000-0002-3852-1894 \\ Silvia Eloiza PRIORE² (ID) 0000-0003-0656-1485 \\ Andréia Queiroz RIBEIRO2 ID) 0000-0001-6546-1252 \\ Fabiane Aparecida Canaan REZENDE ${ }^{1}$ (ID) 0000-0002-5617-8778 \\ Sylvia do Carmo Castro FRANCESCHIN|2 ${ }^{2}$ 0000-0001-7934-4858
}

A B S T R A C T

\section{Objective}

To assess the relationship between food availability, food insecurity and socioeconomic and demographic characteristics of households in the urban area of the state of Tocantins.

\section{Methods}

Population-based, cross-sectional study conducted in 594 households in the urban area of 22 municipalities in the state of Tocantins. A survey was carried out in the households, to collect socioeconomic and demographic

\footnotetext{
1 Universidade Federal do Tocantins, Curso de Nutrição, Grupo de Estudos e Pesquisas em Segurança Alimentar e Nutricional. Av. NS-15, Quadra 109, Norte, s/n., Plano Diretor Norte, 77001-090, Palmas, TO, Brasil. Correspondence to: E. SCHOTT. E-mail: <eloise@uft.edu.br>.

2 Universidade Federal de Viçosa, Departamento de Nutrição e Saúde, Programa de Pós-Graduação em Ciência da Nutrição. Viçosa, MG, Brasil.

Article elaborated from the thesis by E. Schott, entitled "Multidimensional analysis of food and nutritional insecurity in the urban population of the state of Tocantins". Universidade Federal de Viçosa; 2019.

Support: Ministério do Desenvolvimento Social (Ministry of Social Development) (TED n. 08/2014, Case 71000.014305/2014-51). Coordenação de Aperfeiçoamento de Pessoal de Nivel Superior (Capes, Coordination for Higher Education Staff Development). Conselho Nacional de Desenvolvimento Científico e Tecnológico (CNPq, National Council for Scientific and Technological Development) (Process number 311078/2016-8).
}

How to cite this article

Schott E, Priore SE, Ribeiro AQ, Rezende FAC, Franceschini SCC. Food availability and food insecurity in households in the state of Tocantins, Northern Brazil. Rev Nutr. 2020;33:e200100. https://doi.org/10.1590/1678-9865202033e200100 
data, and assess food insecurity using the Brazilian Food Insecurity Scale. Further a food availability questionnaire was applied by the interviewer with the head of the family, who reported on the food and drinks available at home in the last 30 days. The description of the food available in the households resulted in a total of 142 food items that were grouped according to the NOVA classification of foods.

\section{Results}

It was found that $63.3 \%$ of households were in a situation of food insecurity. The median caloric availability found was 2,771.4kcal/per capita/day, with the largest caloric contribution coming from fresh and minimally processed foods, regardless of the degree of food insecurity.

\section{Conclusion}

Food availability was affected by socioeconomic vulnerability and the situation of food insecurity in the families.

Keywords: Diet. Diet surveys. Food and nutrition security. Socioeconomic factors.

\section{RE S U M O}

\section{Objetivo}

Avaliar a relação entre a disponibilidade alimentar, a situação de insegurança alimentar e características socioeconômicas e demográficas de domicílios da zona urbana do Estado do Tocantins.

\section{Métodos}

Estudo de base populacional, do tipo transversal, realizado em 594 domicilios da área urbana de 22 municípios do Estado do Tocantins. A coleta de dados foi realizada nos domicilios, com levantamento de dados socioeconômicos e demográficos, avaliação da insegurança alimentar por meio da Escala Brasileira de Insegurança Alimentar e avaliação da disponibilidade dos alimentos a partir de um questionário de disponibilidade alimentar aplicado pelo entrevistador ao chefe da família, que informou sobre os alimentos e bebidas disponíveis no domicílio nos últimos 30 dias. A descrição dos alimentos disponíveis nos domicílios resultou em um total de 142 itens alimentares que foram agrupados de acordo com a classificação NOVA de alimentos.

\section{Resultados}

Constatou-se que 63,3\% dos domicilios encontravam-se em situação de insegurança alimentar. A disponibilidade calórica mediana encontrada foi de 2.771,4kcal/per capita/dia, sendo a maior contribuição calórica advinda de alimentos in natura e minimamente processados, independente do grau de insegurança alimentar.

\section{Conclusão}

A disponibilidade alimentar foi afetada pela vulnerabilidade socioeconômica e pela situação de insegurança alimentar das familias.

Palavras-chave: Dietas. Inquéritos alimentares. Fatores socioeconômicos. Segurança alimentar e nutricional.

\section{INTRODUCTION}

In Brazil, Food and Nutrition Security (FNS) is defined as the realization of the right of everyone to have regular and permanent access to quality food, in sufficient quantity, without impairing access to other essential needs, based on dietary practices that promote health, respect cultural diversity and are socially, economically and environmentally sustainable [1]. Food and nutrition security encompasses four dimensions: availability, access, use of food and nutrients and stability, considering their interrelationships [2,3]. When any of these elements is infringed, a situation of food and nutritional insecurity is characterized preventing materialization of the human right to Have Access to Adequate Food (HRAF) $[4,5]$. In this connection, in Brazil, several public policies and FNS actions are being developed aiming at the integration of different areas, such as health, agricultural production, food supply, job and income generation, food education and actions to expand access to food [3]. 
The availability and access to healthy foods are prerequisites for the promotion of the individuals' health and nutrition [6]. Therefore, studies about the availability of food at home are essential to assess food and nutritional insecurity, given its multifactorial characteristics, and since the foods available at home are an indication of the family's consumption, just like the biological, psychological, psychosocial, economic factors, among others that also influence the food choices of individuals [7-9].

Currently, the classification of foods according to their processing extension and purpose has been widely used, distributing food in four different groups: fresh or minimally processed foods, processed culinary ingredients, processed foods and ultra-processed foods. This classification is called NOVA and has been used for different purposes, such as: description of changes in food consumption related to ultra-processed products, analysis of the impact of these products consumption on the quality of food and the risk of chronic diseases, development of food guides and assessment of household availability of food in a Family Budget Survey $[10,11]$.

The 2017-2018 Household Budget Survey (HBS) shows that changes have occurred in the Brazilian population diet in recent decades, underscoring the increase of processed and ultraprocessed foods in the households to the detriment of fresh or minimally processed foods and processed culinary ingredients [11]. At the same time a growing excess weight and chronic NonCommunicable Diseases (NCD) has developed due, among other factors, to the population's feeding patterns, characterized by this replacement of traditional basic foods with ultra-processed foods and drinks [12].

Due to the importance of household food availability in the framework of food security, as well as the effects of food processing on food quality and human health, this study aims to assess the relationship between food availability and the socioeconomic, demographic and food insecurity of families living in the urban areas of the State of Tocantins.

\section{METHODS}

This is a population-based, cross-sectional study that is part of the project to strengthen the Food and Nutrition Security System in the States of Amapá, Pará and Tocantins, conducted in the urban area of 22 municipalities in the State of Tocantins. Data collection was carried out between September 2016 and July 2017. The calculation of the sample size representative of the population was performed using the OpenEpi ${ }^{\circledR}$ program and the proportions equation: $n=[D E G S * N p(1-p)] /$ $\left[\left(d 2 / Z 21-\alpha / 2 *(N-1)+p^{*}(1-p)\right]\right.$, where $=$ Population size; $p=$ Frequency $\%$ hypothetical factor in the population; DEGS = Design effect for group surveys and $d=$ Confidence limits (absolute $+/-\%$ ) [13]. At the end, additional $10 \%$ individuals were added for the control of confounding factors, and a total sample of 595 households in the urban area was obtained, distributed in 22 municipalities randomly selected and divided proportionately in the 8 microregions of the State. The households were divided based on a systematic draw proportional to the size of each municipality. Initially, a pilot study was performed in order to test the research equipment, instruments and logistics.

Data collection was carried out in the households, with the application of a semi-structured questionnaire to the head of the family/head of the household, to collect socioeconomic and demographic data. The variables reviewed in this study were: number of residents in the household, the receipt of benefits from the Federal Government's Bolsa Familia Welfare Program; the per capita monthly income in minimum wages, considering the values current in 2016 and 2017, and the situation of household food insecurity, as well as gender, age (in years), self-reported race/skin color, 
education (in years) and paid activity of the interviewee. For the evaluation of food insecurity, the Escala Brasileira de Insegurança Alimentar (EBIA, Brazilian Food Insecurity Scale) was used, which, based on the perception of the head of the family regarding household food insecurity in the last three months, results in a specific level of food insecurity. For households with residents under 18, the scale rank includes food security ( 0 points); mild food insecurity ( 1 to 5 points); moderate food insecurity (6 to 10 points) and severe food insecurity (11 to 14 points). And for households with adult individuals only, the scale classifies as food security ( 0 points); mild food insecurity ( 1 to 3 points); moderate food insecurity (4 to 6 points) and severe food insecurity (7 to 8 points) [14]. In this study, the categories moderate and severe food insecurity were grouped in order to increase the accuracy of the analyses.

Food availability was also assessed using a food availability questionnaire adapted from Dutra et al. [15] and applied by the interviewer to the head of the family, who reported on the food and drinks available at home in the last 30 days. The responses included a detailed description of the food/drinks, stating the quantity available and its form of acquisition (purchase, own production for consumption or donation). The description of the food available in the households yielded a total of 142 food items grouped following the NOVA foods classification of the degree of processing: fresh or minimally processed food, processed culinary ingredients, processed food and ultra-processed food [10].

To calculate the daily energy availability in the household, the methodology suggested by the Food and Agriculture Organization of the United Nations (FAO) as presented by Smith was followed, in which the quantity of each available food is converted into kilocalories using tables of conversion [16]. The caloric and nutrient analysis was performed with the aid of the DietPro ${ }^{\circledR}$ software (version 5i), using the Tabela Brasileira de Composição dos Alimentos (TACO, Brazilian Table of Food Composition) $[17,18]$. When any food was not found in this table, the national reference standard of the Nutrient Database of the National Nutrient Database for Standard Reference was used (USDA) [19].

The energy values were added and divided by 30 , the reference period evaluated, and this was divided by the number of residents of the household, resulting in the per capita/daily food availability. Families that had per capita availability below 2,500kcal/day were classified as being in a situation of food insecurity [16]. In addition, the total and per capita caloric value were divided into the caloric proportion of fresh or minimally processed foods, processed culinary ingredients, processed and ultra-processed foods. The data was entered in duplicate in a Microsoft Excel $2010^{\circledR}$ program, and the consistency assessment and the data statistical treatment was performed with the aid of the Stata ${ }^{\circledR}$ version 14.0 statistical package [20].

The descriptive analysis of the data was performed using absolute and relative frequency for categorical variables and for continuous variables that presented an asymmetric distribution and were expressed by the median and interquartile intervals. To verify the relationship between the food insecurity situations assessed based in the EBIA and FAO methods, Pearson's Chi-Square test was used. In order to ascertain the relationship between the situation of food insecurity (EBIA), residents number and the per capita income with the household availability of food given in kcal per capita, the linear trend test was used; on the other hand, to evaluate the relationship of the other socioeconomic and demographic variables with the food availability (kcal per capita) the Mann-Whitney test was used. For all the analyses, alpha equal to $5 \%$ was adopted as the level of statistical significance.

This study was approved by the Human Research Ethics Committee of the Federal University of Viçosa, Minas Gerais State, under opinion n. 1.561.102, and all participants signed the Free and Informed Consent Form in advance. 


\section{RES U L T S}

A total of 594 households yielded information on food availability and were included in this study. Out of these, $57.6 \%(n=342)$ had up to three residents, $19.2 \%(n=114)$ of the families were beneficiaries of the federal government's Bolsa Familia Welfare Program and $38.7 \%(n=207)$ had family income per capita of up to $1 / 2$ minimum wage. It was found that $63.3 \%(n=376)$ of the households were in a situation of food insecurity according to EBIA results, of which $40.9 \%(n=243)$ in mild food insecurity and $22.4 \%(n=133)$ in moderate or severe food insecurity. Most family heads were women $(77.1 \% ; n=458), 54.7 \%(n=325)$ were aged between 18 and 49 years, were brown skin color (56.4\%; $n=335)$, and had no paid activity $(51.4 \% ; n=305)$, in addition to $23.2 \%(n=138)$ reporting having less than four years formal education (Table 1). Table 2 shows that the median calory

Table 1. Characterization of the families investigated, according to socioeconomic and demographic data. Tocantins, Brazil, 2016/2017 $(n=594)$.

\begin{tabular}{|c|c|c|}
\hline Households & $n$ & $\%$ \\
\hline \multicolumn{3}{|l|}{ Number of residents } \\
\hline Up to 3 & 342 & 57.6 \\
\hline from 4 to 6 & 228 & 38.4 \\
\hline$\geq 7$ & 24 & 4.0 \\
\hline \multicolumn{3}{|l|}{ Beneficiaries of a social welfare program } \\
\hline Yes & 114 & 19.2 \\
\hline No & 480 & 80.8 \\
\hline \multicolumn{3}{|c|}{ Monthly income per capita (minimal wages) ${ }^{*}$} \\
\hline$<1 / 4$ & 48 & 9.0 \\
\hline$\geq 1 / 4$ a $\leq 1 / 2$ & 159 & 29.7 \\
\hline$>1 / 2 \leq 1$ & 195 & 36.4 \\
\hline$>1 \leq 2$ & 93 & 17.4 \\
\hline$>2$ & 40 & 7.5 \\
\hline \multicolumn{3}{|l|}{ Food insecurity situation - EBIA } \\
\hline Food Security & 218 & 36.7 \\
\hline Mild Food Insecurity & 243 & 40.9 \\
\hline Moderate/Severe Food Insecurity & 133 & 22.4 \\
\hline Householder & $\mathrm{n}$ & $\%$ \\
\hline \multicolumn{3}{|l|}{ Gender } \\
\hline Male & 136 & 22.9 \\
\hline Female & 458 & 77.1 \\
\hline \multicolumn{3}{|l|}{ Age (years) } \\
\hline 18 to 49 & 325 & 54.7 \\
\hline 50 to 64 & 145 & 24.4 \\
\hline 65 or more & 124 & 20.9 \\
\hline \multicolumn{3}{|l|}{ Race/skin color (self-declared) } \\
\hline Caucasian/yellow & 137 & 23.1 \\
\hline Black & 107 & 18.0 \\
\hline Brown & 335 & 56.4 \\
\hline Indigenous & 15 & 2.5 \\
\hline \multicolumn{3}{|l|}{ Paid activity } \\
\hline Yes & 289 & 48.6 \\
\hline No & 305 & 51.4 \\
\hline \multicolumn{3}{|l|}{ Years of study } \\
\hline$<4$ & 138 & 23.2 \\
\hline$\geq 4$ e $\leq 8$ & 156 & 26.6 \\
\hline$>8$ & 300 & 50.2 \\
\hline
\end{tabular}

Note: ${ }^{*} \mathrm{n}=535$.

EBIA: Escala Brasileira de Insegurança Alimentar. 
availability found was $2,771.4 \mathrm{kcal} /$ per capita/day, with the greatest proportion originating from fresh and minimally processed foods (1,650.7 kcal/per capita/day), which represents $61.5 \%$ of the calories available.

When food insecurity was assessed based on food availability per capita, it was found that $41.1 \%(n=244)$ of households were in food insecurity according to the method proposed by FAO, that is, they had less than 2,500 kcal/per capita/day available, and of these, $73.0 \%(n=178)$ were also in a situation of food insecurity according to the EBIA. There was an association between the situation of food insecurity observed by EBIA and food insecurity analyzed using the FAO method $(p<0.001)$ (data not shown in tables).

Figure 1 shows the proportion of calories available in families from food according to the degree of food processing in different food insecurity situations, pointing out that fresh and minimally processed foods are available in larger proportion. And the greater the degree of food insecurity, the lower the proportion of caloric contribution from ultra-processed foods.

When assessing the relationship between food availability and the situation of food insecurity and other socioeconomic and demographic variables (Table 3), it was found that the higher the degree of household food insecurity by EBIA, the lower the caloric availability of food $(p<0.001)$. It was also found that families benefiting from the Government Bolsa Familia Welfare Program had lower food availability when compared to those that did not receive the benefit $(p<0.001)$. In addition households

Table 2. Household caloric availability per capita/day, according to the NOVA classification of foods. Tocantins, Brazil, 2016/2017 $(n=594)$.

\begin{tabular}{lc}
\hline Variable & Median (interquartile range) \\
\hline Total kilocalories & $2,771.4(1,956.6-3,697.6)$ \\
Kilocalories of fresh food and minimally processed & $1,650.7(1,172.4-2,263.2)$ \\
Kilocalories of processed culinary ingredients & $591.3(402.7-861.0)$ \\
Processed food kilocalories & $77.9(27.9-155.1)$ \\
Ultra-processed food kilocalories & $284.1(153.1-464.2)$ \\
\hline
\end{tabular}

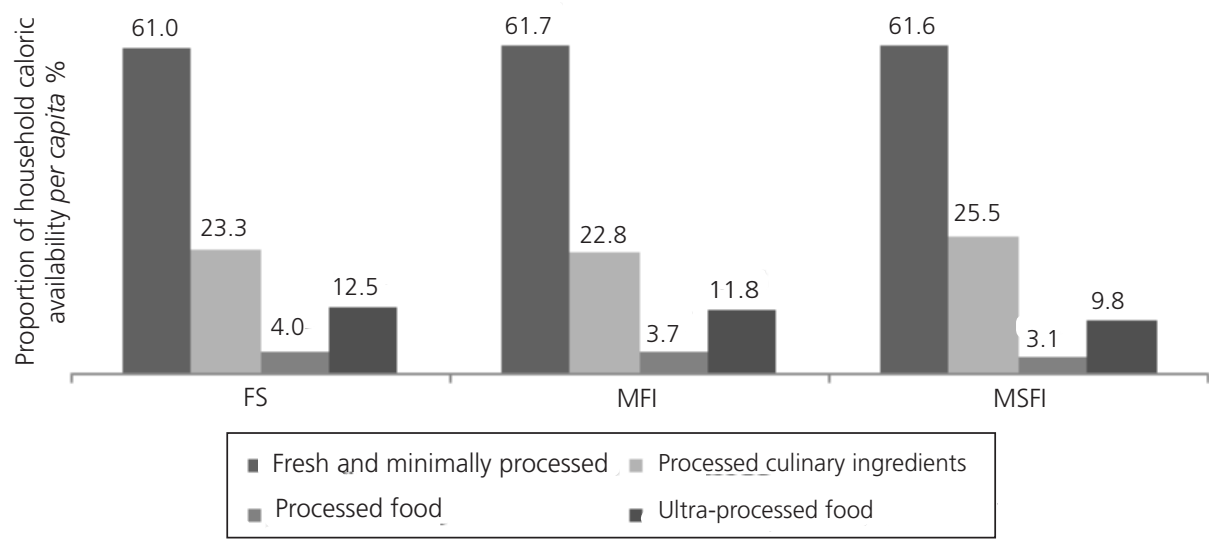

Figure 1. Proportion of household caloric availability per capita, according to the NEW classification of foods and the condition of food insecurity of families. Tocantins, Brazil, 2016/2017 ( $n=594)$.

Note: FS: Food Security; MFI: Mild Food Insecurity; MSFI: Moderate/Severe Food Insecurity. 
Table 3. Food availability per capita according to the situation of food insecurity and socioeconomic and demographic conditions of the households. Tocantins, Brazil, 2016/2017 ( $n=594)$.

\begin{tabular}{|c|c|c|c|c|c|}
\hline \multirow[b]{2}{*}{ Variables } & \multicolumn{5}{|c|}{ Median (interquartile range) } \\
\hline & $\begin{array}{l}\text { kcal }^{*} \text { per capita } \\
\text { total }\end{array}$ & $\begin{array}{l}\text { kcal }{ }^{*} \text { Fresh food and } \\
\text { minimally processed }\end{array}$ & $\begin{array}{c}\text { kcal }{ }^{*} \text { Processed } \\
\text { culinary ingredients }\end{array}$ & $\begin{array}{l}\text { kcal }{ }^{*} \text { Processed } \\
\text { food }\end{array}$ & $\begin{array}{c}\text { kcal }^{*} \text { Ultra-processed } \\
\text { food }\end{array}$ \\
\hline Food insecurity (FI) & $p<0.001^{* *}$ & $p<0.001^{* *}$ & $p=0.001^{* *}$ & $p<0.001^{* *}$ & $p<0.001^{* *}$ \\
\hline Food Security & $\begin{array}{c}3,017.7 \\
(2337.3-4088.6)\end{array}$ & $\begin{array}{c}1,860.5 \\
(1364.0-2514.4)\end{array}$ & $\begin{array}{c}627.6 \\
(471.8-949.8)\end{array}$ & $\begin{array}{c}109.7 \\
(54.9-196.7)\end{array}$ & $\begin{array}{c}328.7 \\
(220.8-523.7)\end{array}$ \\
\hline Mild FI & $\begin{array}{c}2,683.9 \\
(1902.8-3499.3)\end{array}$ & $\begin{array}{c}1,555.2 \\
(1126.1-2194.8)\end{array}$ & $\begin{array}{c}538.2 \\
(368.1-806.4)\end{array}$ & $\begin{array}{c}67.7 \\
(23.6-138.3)\end{array}$ & $\begin{array}{c}277.4 \\
(162.8-423.5)\end{array}$ \\
\hline Moderate Severe FI & $\begin{array}{c}2,361.2 \\
(1485.9-3509.2)\end{array}$ & $\begin{array}{c}1,329.2 \\
(935.0-2094.6)\end{array}$ & $\begin{array}{c}537.6 \\
(334.7-806.4)\end{array}$ & $\begin{array}{c}42.6 \\
(12.3-134.2)\end{array}$ & $\begin{array}{c}176.4 \\
(91.7-348.0)\end{array}$ \\
\hline Welfare Assistance benefit & $p<0.001^{* * *}$ & $p<0.001^{* * *}$ & $p<0.001^{* * *}$ & $p<0.001^{* * *}$ & $p<0.001^{* * *}$ \\
\hline Yes & $\begin{array}{c}1,974.3 \\
(1359.4-2829.1)\end{array}$ & $\begin{array}{c}1,164.1 \\
(932.6-1684.4)\end{array}$ & $\begin{array}{c}394.6 \\
(269.2-580.2)\end{array}$ & $\begin{array}{c}43.6 \\
(13.7-106.9)\end{array}$ & $\begin{array}{c}229.3 \\
(90.2-353.6)\end{array}$ \\
\hline No & $\begin{array}{c}2,913.5 \\
(2149.5-3923.9)\end{array}$ & $\begin{array}{c}1,816.8 \\
(1269.7-2398.5)\end{array}$ & $\begin{array}{c}626.4 \\
(437.8-953.7)\end{array}$ & $\begin{array}{c}84.6 \\
(35.8-165.2)\end{array}$ & $\begin{array}{c}294.3 \\
(172.2-483.3)\end{array}$ \\
\hline Children under 18 & $p<0.001^{* * *}$ & $p<0.001^{* * *}$ & $p<0.001^{* * *}$ & $p=0.003^{* * *}$ & $p=0.384$ \\
\hline Yes & $\begin{array}{c}2,254.2 \\
(1652.1-3006.2)\end{array}$ & $\begin{array}{c}1,342.1 \\
(999.2-1899.7)\end{array}$ & $\begin{array}{c}448.3 \\
(307.6-631.7)\end{array}$ & $\begin{array}{c}63.9 \\
(27.1-136.2)\end{array}$ & $\begin{array}{c}284.1 \\
(148.7-447.0)\end{array}$ \\
\hline No & $\begin{array}{c}3,282.4 \\
(2570.0-4499.0)\end{array}$ & $\begin{array}{c}2,031.5 \\
(1460.7-2835.6)\end{array}$ & $\begin{array}{c}747.3 \\
(553.3-1115.8)\end{array}$ & $\begin{array}{c}94.3 \\
(32.7-178.7)\end{array}$ & $\begin{array}{c}283 \\
(160.4-480.3)\end{array}$ \\
\hline Residents number & $p<0.001^{* *}$ & $p<0.001^{* *}$ & $p<0.001^{* *}$ & $p<0.001^{* *}$ & $p<0.001^{* *}$ \\
\hline up to 3 & $\begin{array}{c}3,272.1 \\
(2571.6-4448.4)\end{array}$ & $\begin{array}{c}1,986.2 \\
(1452.9-2877.3)\end{array}$ & $\begin{array}{c}733.6 \\
(534.6-1106.4)\end{array}$ & $\begin{array}{c}93.2 \\
(36.6-182.7)\end{array}$ & $\begin{array}{c}317.9 \\
(175.0-512.9)\end{array}$ \\
\hline from 4 to 6 & $\begin{array}{c}2,148.7 \\
(1590.9-2870.1)\end{array}$ & $\begin{array}{c}1,316.7 \\
(971.6-1823.3)\end{array}$ & $\begin{array}{c}447.1 \\
(307.5-619.4)\end{array}$ & $\begin{array}{c}64.5 \\
(27.7-122.8)\end{array}$ & $\begin{array}{c}244.1 \\
(142.0-383.9)\end{array}$ \\
\hline$\geq 7$ & $\begin{array}{c}1,656.7 \\
(1202.2-1955.6)\end{array}$ & $\begin{array}{c}993.1 \\
(761.7-1314.0)\end{array}$ & $\begin{array}{c}307.3 \\
(247.3-394.6)\end{array}$ & $\begin{array}{c}26.8 \\
(10.1-70.9)\end{array}$ & $\begin{array}{c}136.8 \\
(79.2-285.4)\end{array}$ \\
\hline Per capita income ${ }^{* * * *}$ & $p<0.001^{* *}$ & $p<0.001^{* *}$ & $p<0.001^{* *}$ & $p<0.001^{* *}$ & $p<0.001^{* *}$ \\
\hline up to $1 / 4$ & $\begin{array}{c}1,695.5 \\
(1131.9-2615.1)\end{array}$ & $\begin{array}{c}1,042.3 \\
(720.7-1694.2)\end{array}$ & $\begin{array}{c}326.3 \\
(249.2-556.9)\end{array}$ & $\begin{array}{c}20.7 \\
(3.5-56.8)\end{array}$ & $\begin{array}{c}115.8 \\
(67.3-234.6)\end{array}$ \\
\hline from $1 / 4$ to $1 / 2$ & $\begin{array}{c}2,151.8 \\
(1712.5-2871.5)\end{array}$ & $\begin{array}{c}1,694.2 \\
(1020.1-1858.8)\end{array}$ & $\begin{array}{c}494.4 \\
(351.3-715.9)\end{array}$ & $\begin{array}{c}57.2 \\
(17.2-130.0)\end{array}$ & $\begin{array}{c}214.2 \\
(125.7-367.9)\end{array}$ \\
\hline$>1 / 2$ to 1 & $\begin{array}{c}3,202.1 \\
(2386.5-4228.2)\end{array}$ & $\begin{array}{c}2,016.9 \\
(1347.7-2632.9)\end{array}$ & $\begin{array}{c}681.2 \\
(487.7-1084.3)\end{array}$ & $\begin{array}{c}88.1 \\
(39.2-169.7)\end{array}$ & $\begin{array}{c}302 \\
(175.6-508.7)\end{array}$ \\
\hline$>1$ up to 2 & $\begin{array}{c}3,263.9 \\
(2655.0-4376.8)\end{array}$ & $\begin{array}{c}1,937.8 \\
(1522.9-2667.1)\end{array}$ & $\begin{array}{c}724.4 \\
(538.2-1030.6)\end{array}$ & $\begin{array}{c}114.2 \\
(63.5-206.0)\end{array}$ & $\begin{array}{c}409.7 \\
(244.4-615.9)\end{array}$ \\
\hline$>2$ & $\begin{array}{c}3,218.9 \\
(2659.8-4727.2)\end{array}$ & $\begin{array}{c}1,879 \\
(1495.2-2846.9)\end{array}$ & $\begin{array}{c}714.5 \\
(493.7-902.6)\end{array}$ & $\begin{array}{c}142.9 \\
(69.4-218.1)\end{array}$ & $\begin{array}{c}400.1 \\
(259.6-543.9)\end{array}$ \\
\hline
\end{tabular}

Note: ${ }^{*}$ Kcal: kilocalory; ${ }^{* *} p$ : Linear Trend; ${ }^{* * *} p$ : Mann-Whitney Test; ${ }^{* * * *} \mathrm{n}=535$.

with residents under 18 years of age had lower caloric availability compared to households that had no residents under 18 ( $p<0.005)$, except for ultra-processed foods. The number of residents also influenced the availability of food; in that case, the more residents in the household, the lower the availability $(p<0.001)$. Food availability had a direct and statistically significant relationship with per capita income, that is, the higher the income, the greater the availability $(p<0.001)$.

It is important to highlight that the household availability of food presented a statistically significant relationship with food insecurity and socioeconomic and demographic variables $(p<0.001)$. Only the per capita availability of ultra-processed foods among households with or without children under 18 did not show statistical significance $(p=0.384)$. 


\section{DISCUSSION}

The availability of food in the house is influenced by aspects such as family composition and income, culture, characteristics of the local market, food production for self-consumption and food donations, in addition to advertising and the price of food supplies [21-23]. In this study, it was observed that the median availability per capita of food $(2,771.4 \mathrm{kcal})$ was lower than the findings by Dutra et al. who reported availability of 3,121.2 kcal/per capita/day in their investigation in the rural area of the State of Minas Gerais [24]. However, it was higher than that mentioned in the 2008-2009 Household Budget Surveys (HBS), where the average food availability of Brazilian households was $1,611 \mathrm{kcal} /$ per capita/day [25].

In this study, fresh and minimally processed foods corresponded to $61 \%$ of the total calories available in households, a percentage higher than that found in HBS 2017-2018, which was 49.5\%, with the North and Northeast regions presenting a greater contribution of fresh foods or minimally processed food in the total caloric availability of food $(58.2 \%$ and $54.5 \%$, respectively) when compared to other regions of the country [11].

According to the latest Food Balance prepared by the Food and Agriculture Organization of the United Nations (FAO), Brazil has sufficient food availability to serve the entire Brazilian population, with a total of $3,248 \mathrm{kcal} /$ per capita/day of food available in the country [26]. However, it is emphasized that the family income allocated to the purchase of food plays an important role in obtaining healthier foods by a considerable part of the Brazilian population, since socioeconomic factors can influence the access and intake of this type of food [27].

Based on the data collected, a high caloric availability from fresh and minimally processed foods was observed, derived from foods such as rice, beans, milk, pasta and wheat, corn and cassava flours, besides fruits and vegetables (data not presented in a table). As in this investigation, a study conducted in 502 households in the region Zona da Mata and 458 in the semiarid region of Northeastern Brazil also found a high availability of foods such as rice, pasta, beans, cassava flour and corn, milk, sugar and vegetable oil [7].

In families in a situation of food insecurity, in addition to the lower consumption of processed foods due to economic restriction, other factors may be associated to the higher consumption of regional foods, mainly fruits and vegetables, such as: seasonality and easy access due to free availability from cultivation in the backyard or close to home, eliminating the purchase of this food [28]. Since the households assessed are located in small municipalities in the inner part of the State, where the options for food outlets are often restricted, the high household availability of fresh and minimally processed food at home is justified, since most of these foods may come from backyard production for self-consumption, from donations and/or from availability due to seasonality and regionality of the food.

This highlights the role of urban agriculture in ensuring food and nutritional security by improving access to food, since food grown in backyards contribute to a healthier family diet and, as a consequence, they release part of the family income from the purchase of food [29,30]. In addition, according to the Food Guide for the Brazilian Population dated 2014, adequate and healthy food must come from a sustainable food system and be based on adequate and sustainable production practices, as a way of ensuring food quality, providing food and nutritional health and security for families [31]. 
In addition to the high percentage of fresh and minimally processed food found in the sample, almost $1 / 4$ of the caloric contribution came from processed culinary ingredients, which include raw materials such as sugar and oil, which are substantially caloric. It is noteworthy that the situation of food insecurity or difficult access can often lead families to prefer highly energetic foods, and a monotonous diet, with few nutrients, may be associated with low family income, that can cause unhealthy food selection [32,33].

Furthermore, the results pointed out here corroborate with studies that reported less food availability among families with food insecurity or socioeconomic vulnerability when compared to families with food security and higher income [34,35]. However, unlike this study, Martins and Monteiro observed greater expenditure on food and greater availability of fresh food and culinary ingredients, in households benefited by the Government Bolsa Familia Welfare Program, when compared to non-beneficiaries [36].

It should be observed that the greater the income, the greater the caloric contribution of processed and ultra-processed foods available in the households assessed. This finding is supported by the data from the HBS 2017-2018, which indicates that with a raising income there is also an increase in the caloric participation of processed and ultra-processed foods in the households [11]. In contrast, the Brazilian low-income population still buys less processed or ultra-processed products, unlike developed countries like Canada and the United Kingdom, where the proportion of ultra-processed products exceeds $60 \%$ of the total calories available [36].

Also according to the HBS food acquisition records 2008-2009, it was found that the average price resulting from the association of fresh and minimally processed foods with culinary ingredients was lower compared to processed and ultra-processed products, indicating an economic advantage in the preparation of meals at home, as recommended by the Food Guide for the Brazilian Population. However, the variation in food prices in recent years, convenience and advertising, have favored the consumption of processed and ultra-processed foods by the general population [23].

Another negative point related to the consumption of ultra-processed foods is that they tend to have higher energy density, less fiber and are richer in sugar when compared to fresh or minimally processed foods, especially when combined with culinary ingredients such as salt, sugar and fats [37]. In addition, high consumption of ultra-processed foods has been associated with an increased risk of cardiovascular disease, overweight and obesity, hypertension and cancer [38-42].

It is important to highlight that in this study it was found a reduced availability of food in households with a higher number of residents, as well as in those with individuals under 18 years of age. This can be explained, since the sufficiency of food at home depends on its availability, access and intrafamily consumption, and is influenced by the size and composition of the family [21]. In addition, it is inferred that the inadequate food consumption of a family head due to the non-availability of all food groups at home, implies in a similar food consumption of the other household residents [43].

Preparation of meals at home using unprocessed, minimally processed foods and culinary ingredients is also important as a way of promoting adequate and healthy food consumption by children [44]. Therefore, feeding practices should provide food in sufficient quantity and quality, that meet the nutritional needs of children and ensure their proper development, since inadequate food consumption in childhood tends to develop overweight and obesity and other chronic diseases at an early age [45].

Thus, it is necessary to implement food and nutrition security public policies that cover different dimensions inherent to food, such as availability, access and production of food, income, health and education and further implement public policies governing food prices to improve household 
access to greater food diversity [21]. In addition the promotion and encouragement of food production in the houses' backyards, can positively impact food availability and families' food security $[28,46]$.

\section{CONCLUSION}

This study indicated that the greatest caloric contribution available in the households originated from fresh and minimally processed foods. It also showed that the availability of food was affected both by the socioeconomic vulnerability of the families and by the situation of food insecurity in the households. Therefore, the need to carry out multisectorial interventions to improve the availability and access to food in small municipalities such as those assessed in this investigation stands out, as well as the encouragement of urban and peri-urban agriculture and policies and programs to promote food health, aiming at providing greater availability of healthy foods, reducing consumption of ultra-processed products and ensuring food and nutritional security for families. Finally, due to the scarcity of studies of this nature for this State, especially for the interior part of the State, it is of major importance to conduct further research in connection with food and nutrition security, availability and consumption of food and eating habits of the population.

\section{CONTRIBUTORS}

E. SCHOTT, conception and design of the study, data collection, analysis and interpretation, writing of the article, critical review of the content and approval of the final version. S.E. PRIORE, A.Q. RIBEIRO, F.A.C. REZENDE, and S.C.C. FRANCESCHINI conception and design of the study, analysis and data interpretation, critical review of the content approval of the final version.

\section{REFERE N CES}

1. Brasil. Lei $n^{\circ}$ 11.346, de 15 de setembro de 2006. Cria o Sistema Nacional de Segurança Alimentar e Nutricional: SISAN com vistas em assegurar o direito humano à alimentação adequada e dá outras providências. Brasília: Diário Oficial da União; 2006.

2. Roberts AA, Osadare JO, Inem VA. Hunger in the midst of plenty: a survey of household food security among urban families in Lagos State, Nigéria. J Public Health Afr. 2019;10(1):885. https://doi.org/10.4081/ jphia.2019.885

3. Calmon LS, Santos SMC, Pereira MHQ. Acesso aos alimentos e segurança alimentar e nutricional: avaliação da situação em municípios baianos. Demetra; 2016; 11(Supl.1):1351-66.

4. Rocha NP, Milagres LC, Novaes JF, Franceschini SCC. Associação de insegurança alimentar e nutricional com fatores de risco cardiometabólicos na infância e adolescência: uma revisão sistemática. Rev Paul Pediatr. 2016;34(2):225-33. https://doi.org/10.1016/j.rppede.2016.01.006

5. Guerra LDS, Cervato-Mancuso AM, Bezerra ACD. Alimentação: um direito humano em disputa: focos temáticos para compreensão e atuação em segurança alimentar e nutricional. Ciênc Saúde Coletiva. 2019;24(9):3369-94. https://doi.org/10.1590/1413-81232018249.20302017

6. Lunze, K, Yurasova E, Idrisov B, Gnatienko N, Migliorini L. Food security and nutrition in the Russian Federation a health policy analysis. Glob Health Action. 2015;8:27537. https://doi.org/10.3402/gha.v8.27537

7. Osório MM, Ribeiro MA, Costa EC, Silva SPO, Fernandes CE. Disponibilidade familiar de alimentos na Zona da Mata e semi-árido do Nordeste do Brasil. Rev Nutr. 2009;22(3):319-29.

8. Defante LR, Nascimento LDO, Lima-Filho DO. Comportamento de consumo de alimentos de famílias de baixa renda de pequenas cidades brasileiras: o caso de Mato Grosso do Sul. Interações. 2015;16(2):265-76. https://doi.org/10.1590/151870122015203 
9. Pereira CM, Silva AL, Sá MI. Fatores que influenciam os comportamentos alimentares: questionário das escolhas alimentares dos adolescentes. Psic Saúde Doenças. 2015;16(3):421-38.

10. Monteiro CA, Cannon G, Levy RB, Moubarac JC, Jaime P, Martins AP, et al. NOVA. The star shines bright. World Nutr. 2016;7(1-3):28-38. https://worldnutritionjournal.org/index.php/wn/article/view/5/4

11. Instituto Brasileiro de Geografia e Estatística. Pesquisa de Orçamentos Familiares 2017-2018: avaliação nutricional da disponibilidade domiciliar de alimentos no Brasil. Rio de Janeiro: Instituto 2020.

12. Sparrenberger K, Friedrich RR, Schiffner MD, Schuch I, Wanger MB. Ultra-processed food consumption in children from a Basic Health Unit. J Pediatr. 2015;91(6):535-42. https://doi.org/10.1016/j.jped.2015.01.007

13. Dean AG, Sullivan KM, Soe MM. OpenEpi: Open Source Epidemiologic Statistics for Public Health. Atlanta: OpenEpi; 2013 [cited 2019 May 21]. Available from: www.OpenEpi.com

14. Instituto Brasileiro de Geografia e Estatística. Pesquisa Nacional por Amostra de Domicílios 2013: Suplemento de Segurança Alimentar. Rio de Janeiro: Instituto 2014.

15. Dutra LV, Souza LM, Santos RHS, Priore SE. Disponibilidade alimentar para famílias residentes na zona rural: situação de segurança ou insegurança alimentar e nutricional. Segur Aliment Nutr. 2014;21(1):320-9.

16. Smith LC. The use of household expenditure surveys for the assessment of food insecurity. Proceedings of the International Scientific Symposium; 2002 June 26-28; Rome, Italy. Rome: Food And Agriculture Organization of the United Nations; 2003 [cited 2019 May 21]. Available from: http://www.fao.org/3/y4249e/y4249e00. htm

17. Agromídia Software Ltda. DietPro: software de avaliação nutricional e prescrição dietética. versão 5. Viçosa: AS Sistema; 1997.

18. Núcleo de Estudos e Pesquisas em Alimentação (Campinas). Tabela Brasileira de Composição de Alimentos [TACO]. versão 2. Campinas: Universidade Estadual de Campinas; 2011.

19. Department of Agriculture (United States). USDA National Nutrient Database for Standard Reference: Release 28. Washington: Departament; 2016 [cited 2019 May 21]. Available from: https://www.ars.usda.gov/ northeast-area/beltsville-md-bhnrc/beltsville-human-nutrition-research-center/methods-and-application-offood-composition-laboratory/mafcl-site-pages/sr11-sr28/

20. StataCorp.Stata Statistical Software: Release 14. College Station: StataCorp LP; 2015.

21. Guerra LDS, Espinosa MM, Bezerra ACD, Guimarães LV, Martins MSAS. Desafios para a Segurança Alimentar e Nutricional na Amazônia: disponibilidade e consumo em domicílios com adolescentes. Ciênc Saúde Coletiva. 2018;23(12):4043-54. https://doi.org/10.1590/1413-812320182312.26352016

22. Harris-Fry H, Azad K, Kuddus A, Shaha S, Nahar B, Hossen M. Socio-economic determinants of household food security and women's dietary diversity in rural Bangladesh: a cross-sectional study. J Health Popul Nutr. 2015;33:2. https://doi.org/10.1186/s41043-015-0022-0

23. Claro RM, Maia EG, Costa BVL, Diniz DP. Preço dos alimentos no Brasil: prefira preparações culinárias a alimentos ultraprocessados. Cad Saúde Pública. 2016;32(8):e00104715. https://doi.org/10.1590/0102$311 \times 00104715$

24. Dutra, LV, Morais DC, Santo RHS, Franceschini SCC, Priore, SE Contribution of the production for self consumption to food availability and food security in households of the rural area of a Brazilian city. Ecol Food Nutr. 2018;57(4):282-300. https://doi.org/10.1080/03670244.2018.1488250

25. Instituto Brasileiro de Geografia e Estatística. Pesquisa de Orçamentos Familiares 2008-2009: avaliação nutricional da disponibilidade domiciliar de alimentos no Brasil. Rio de Janeiro: Instituto 2010.

26. Food and Agriculture Organization of the United Nations. Faostat: food balance sheets. 2017. Rome: Organization; 2017 [cited 2020 Mar 31]. Available from: http://www.fao.org/faostat/en/\#data/FBS/visualize.

27. Borges CA, Claro RM, Martins APB, Villar BS. Quanto custa para as famílias de baixa renda obterem uma dieta saudável no Brasil? Cad Saúde Pública. 2015;31(1):137-48. https://doi.org/10.1590/0102-311X00005114

28. Coelho SEAC, Gubert MB. Insegurança alimentar e sua associação com consumo de alimentos regionais brasileiros. Rev Nutr. 2015;28(5):555-67. https://doi.org/10.1590/1415-52732015000500010

29. Sousa RPO, Calaça M. Agricultura urbana: uma nova alternativa para a produção de alimentos e melhor qualidade ambiental para a cidade. Camp Territ Rev Geo Agrar. 2019;14(32):239-265. https://doi.org/10. 14393/RCT143210 
30. Pires VC. Agricultura urbana como fator de desenvolvimento sustentável: um estudo na região metropolitana de Maringá. Rev Pesq Deb. 2016;27(2):50.

31. Paiva JB, Magalhães LM, Santos SMC, Santos LAS, Trad LAB. A confluência entre o "adequado" e o "saudável": análise da instituição da noção de alimentação adequada e saudável nas políticas públicas do Brasil. Cad Saúde Pública. 2019;35(8):e00250318. https://doi.org/10.1590/0102-311×00250318

32. Nunnery DL, Labban JD, Dharod JM. Interrelationship between food security status, home availability of variety of fruits and vegetables and their dietary intake among low-income pregnant women. Public Health Nutr. 2017; 21(4):807-815. https://doi.org/10.1017/\$1368980017003032

33. Trivelatto PT., Morais DC., Lopes SO., Miguel ES., Franceschini SCC., Priore SE. Insegurança alimentar e nutricional em famílias do meio rural brasileiro: revisão sistemática. Ciênc. Saúde Coletiva. 2019;24(3:865-874. https://doi.org/10.1590/1413-81232018243.05352017

34. Poulsen MN, Bailey-Davis L, Pollak J, Hirsch AG, Schwartz BS. Household food insecurity and home food availability in relation to youth diet, body mass index, and adiposity. J Acad Nutr Diet. 2019;119(10):1666-75. https://doi.org/10.1016/j.jand.2019.01.001

35. Dodd W, Cerna MG, Orellena P, Humphries S, Sadoine ML, Zombré D, et al. Factors associated with seasonal food insecurity among small-scale subsistence farming households in rural Honduras. Int J Environ Res Public Health. 2020;17(3):706. https://doi.org/10.3390/ijerph17030706

36. Martins APB, Monteiro CA. Impact of the Bolsa Família program on food availability of low-income Brazilian families: a quasi experimental study. Bmc Public Health. 2016;16(1):827. https://doi.org/10.1186/s12889-0 16-3486-y

37. Louzada MLC, Martins APB, Canella DS, Baraldi LG, Levy RB, Claro RM, et al. Alimentos ultraprocessados e perfil nutricional da dieta no Brasil. Rev Saúde Pública 2015;49(1):38. https://doi.org/10.1590/\$0034-8 910.2015049006132

38. Srour B, Fezeu LK, Kesse-Guyot E, Allès B, Méjean C, Andrianasolo RM, et al. Ultra-processed food intake and risk of cardiovascular disease: prospective cohort study (NutriNet-Santé). Br Med Assoc J. 2019;365:11451. https://doi.org/10.1136/bmj.I1451

39. Mendonça RD, Pimenta AM, Gea A, De la Fuente-Arrillaga C, Martinez-Gonzalez MA, Lopes AC, et al. Ultraprocessed food consumption and risk of overweight and obesity: the University of Navarra Follow-Up (SUN) cohort study. Am J Clin Nutr. 2016;104(5):1433-40. https://doi.org/10.3945/ajcn.116.135004

40. Louzada MLC, Baraldi LG, Steele EM, Martins APB, Canella DS, Moubarac J-C, et al. Consumption of ultraprocessed foods and obesity in Brazilian adolescents and adults. Prev Med. 2015;81:9-15. https://doi. org/10.1016/j.ypmed.2015.07.018

41. Mendonça RD, Lopes AC, Pimenta AM, Gea A, Martinez-Gonzalez MA, Bes-Rastrollo M. Ultra-processed food consumption and the incidence of hypertension in a mediterranean cohort: the seguimiento Universidad de Navarra Project. Am J Hypertens. 2017;1;30(4):358-66. https://doi.org/10.1093/ajh/hpw137

42. Fiolet T, Srour B, Sellem L, Kesse-Guyot E, Allès B, Méjean C, et al. Consumption of ultra-processed foods and cancer risk: results from NutriNet-Santé prospective cohort. Br Med Assoc J. 2018;360 https://doi. org/10.1136/bmj.k322

43. Almeida JÁ, Santos AS, Nascimento MAO, Oliveira JVC, Silva DG, Mendes-Netto RS. Fatores associados ao risco de insegurança alimentar e nutricional em famílias de assentamentos rurais. Ciênc. Saúde Coletiva. 2017;22(2):479-88. https://doi.org/10.1590/1413-81232017222.27102015

44. Martins CA, Machado PP, Louzada MLC, Levy RB, Monteiro CA. Parents' cooking skills confidence reduce children's consumption of ultraprocessed foods. Appetite. 2020;144(1). https://doi.org/10.1016/j. appet.2019.104452

45. Carvalho CA, Fonsêca PCA, Priore SE, Franceschini SCC, Novaes JF. Consumo alimentar e adequação nutricional em crianças brasileiras: revisão sistemática. Rev Paul Ped. 2015;33(2):211-21. https://doi.org/10. 1016/j.rpped.2015.03.002

46. Akpaki K, Galibois I, Sall M, Blaney S. Assessing the food availability and food insecurity situation among communities of matam region, Senegal. Ecol Food Nutr. 2020;9:1-20. https://doi.org/10.1080/03670244.2 020.1733993. 